\title{
Chemical composition and nutritional value of some varieties of soybean cultivated in Mongolia
}

\author{
Khongorzul Mungunkhuyag ${ }^{1}$, Zolzaya Bayarsukh², Oyundelger Ganzorig $^{1}$, Batjargal Batdorj ${ }^{1 *}$ \\ ${ }^{1}$ School of Arts and Sciences, National University of Mongolia, Zaluuchuud avenue 14201, Ulaanbaatar, Mongolia \\ ${ }^{2}$ Institute of Chemistry and Chemical Technology, Mongolian Academy of Sciences, Peace avenue 13330, Ulaanbaatar, \\ Mongolia \\ *Corresponding author: batjargal@ num.edu.mn
}

https://orcid.org/0000-0001-5704-0087

\begin{tabular}{lll}
\hline Received: 30.03 .2021 & Revised: 14.06 .2021 & Accepted: 15.09 .2021 \\
\hline
\end{tabular}

\begin{abstract}
Soybean has a lot of benefits for human nutrition, well-being and soil nutrition. Soybean seed contain higher concentration of protein and fat. The objective of this work was to evaluate the nutritional composition and mineral contents in soybean seeds of four different varieties of soybean for their future application as food products. The soybeans were cultivated in Mongolia. The moisture, protein, crude fat, reducing carbohydrate's concentrations were determined by Kjeldahl, Soxhlet and Bertrand's method in dried soybean seeds, and the calory of $100 \mathrm{~g}$ seed was calculated. The mineral concentration in the ash was determined by ICP-OES method. Among them, the Severnaya- 4 variety contained the highest amount of protein, $31.5 \%$, the Sibiryachka variety had the highest concentration of crude fat, $20.35 \%$, and reducing sugar, $1.24 \%$. Moreover, the Severnaya-4 and Sibiryachka soybean seeds had the highest mineral concentration. The lower concentration of protein of these four soybean varieties was probably due to the lower temperature during the seed-filling period in Mongolia. Sibiryachka and OAC vision had the highest amount of energy in $100 \mathrm{~g}$ raw seed than other two varieties. The Severnaya- 4 and Sibiryachka soybean seeds could be better sources for protein, fat and minerals than the Nei dou-4 and OAC vision varieties.
\end{abstract}

Keywords: soybean, nutrient contents, macroelements, microelements

\section{Introduction}

Soybean, Glycine max L. (Merr.), is one of the most cultivated plants throughout the world. It is a native of Southeast Asia, especially China, where it has been cultivated for several thousand years. Soybeans are used to produce daily food products such as tofu, miso, tempeh, soy sauce, soy oil, and soymilk. According to the standard reference of the U.S. Department of Agriculture mature, raw soybeans contain approximately $36.49 \mathrm{~g}$ of protein, $19.94 \mathrm{~g}$ of fat, and $30.16 \mathrm{~g}$ of carbohydrate per $100 \mathrm{~g}$ [1]. These amounts can vary among soybean varieties. Soybeans are much higher in potassium, phosphorus, calcium, and magnesium, as well as pyridoxine and vitamin $\mathrm{K}$ than other legume plants [2]. These nutritional properties make soybean a potential source of protein, fat, carbohydrate, and vitamins for people and animal feed. Furthermore, it contains all essential amino acids in sufficient quantity for human daily intake [3].

Besides its stated utilization as food and animal feed, soybean has the ability to improve soil properties through its deep and proliferated tap-root system, residue incorporation by way of shedding leaves as well as green manuring crop and contribution to soil nitrogen enrichment through biological nitrogen fixation in association with nodule-forming bacteria (Bradyrhizobium). Most of the fixed nitrogen is used for growing soybean itself, but some are left unused in the soil and some in the nodules. Once soybean is harvested, this leftover nitrogen is available to the next crop [4]. On an average, 50-60\% of soybean nitrogen demand was met by biological $\mathrm{N}_{2}$ fixation [5]. Tuul D. and Bayarsaikhan B. had determined that legume plants obtained needed nitrogen from atmosphere $/ 53.8-64.6 \% /$ and soil $/ 33.9-43.9 \% /$ by 
using ${ }^{15} \mathrm{~N}$ isotope [6]. These features made soybean suitable for mixed and sequential cropping systems. Cultivation of soybean in Mongolia started in places such as Zuun kharaa in Selenge province, Bulgan in Umnugobi province, the Khalkh river research institution in Dornod province during the period of 1958 - 1966. From that time until today many experiments have been conducted by researchers in Mongolia to grow different varieties of soybean, evaluate their yields, and determine their nitrogen intake source. Research on the soybean cultivation period and seed standards had been accomplished in $2010-2014$ and the resulting three soybean sorts were promising to grow in Mongolia [7]. In 2017, OAC vision was certified as a settled soybean variety by the Ministry of Food, Agriculture and Light Industry in Mongolia [8]. This variety contains $27.4 \%$ protein, $27.2 \%$ starch, and $20.2 \%$ fat. In 2018 , Sibiryachka was proven as a promising variety, and it contains $32.4 \%$ protein, $27.1 \%$ starch, and $14.7 \%$ fat [9]. Also, Severnaya-4 was verified as a variety to be tested in 2014 [10], it contains $31.5 \%$ protein, $27.1 \%$ starch, and $16.8 \%$ fat [9].

\section{Materials and methods}

\section{Materials}

Seeds of four soybean varieties (Sibiryachka, Severnaya-4, OAC vision, and Nei dou-4) were used for the study. These soybeans were grown on the experimental field of the Institute of Plant and
Valuable health benefits of soy products attract public attention and many research works have been carried out in recent years. Soy protein lowers the circulating low-density lipoprotein (LDL)cholesterol level [1, 8, 9], and in 1998 scientists revealed that soy globulin $7 \mathrm{~S}$ subunits increased uptake and degradation of LDL [13]. The most peculiar feature of soybean is its high content in isoflavones. Isoflavones have many health benefits. For instance, women who are consuming soybean products daily, especially Asian women, are less likely to suffer from hot flashes and other symptoms during menopause. Isoflavones help to alleviate hot flashes and improve arterial health in menopausal women [1]. Consuming soybean products can provide many beneficial agents such as vitamins, minerals, fiber, and flavonoids and these agents reduce the risk for chronic diseases including cancer, stroke and heart disease [14].

The objective of this work was to evaluate the chemical composition of the macronutrients and micronutrients in soybean seeds of four different varieties or their future application as food products.

Agricultural Sciences in Orkhon sum, Darkhan-Uul province in 2016. Information about their origin is presented in Table 1.

The origin of four soybean varieties. This information is taken from a research report [7]

\begin{tabular}{|c|c|c|c|}
\hline $\begin{array}{c}\text { Soybean } \\
\text { variety }\end{array}$ & $\begin{array}{l}\text { Genetic reservoir } \\
\text { catalog number }\end{array}$ & Origin & $\begin{array}{c}\text { Country of } \\
\text { origin }\end{array}$ \\
\hline Nei dou-4 & И-21802 & $\begin{array}{c}\text { Hulunbeier Agricultural Science Research } \\
\text { Institute, Neimenggu }\end{array}$ & China \\
\hline OAC vision & И-19334 & $\begin{array}{l}\text { University of Saskatchewan, } \\
\text { College of Agriculture and Bioresources }\end{array}$ & Canada \\
\hline Severnaya-4 & И-22545 & Krasnoyarsk Research Institute of Agriculture & Russia \\
\hline Sibiryachka & И-22542 & Krasnoyarsk Research Institute of Agriculture & Russia \\
\hline
\end{tabular}

\section{Methods}

To evaluate the biochemical contents of four soybean varieties, work on determination of moisture, ash, crude fat, reducing sugar, and protein was carried out. And the total amount of carbohydrate was calculated by subtracting contents of protein, crude fat, and ash from dry weight. Before the analysis, soybeans were grounded by mortar and pestle.

To determine moisture, a 0.5 to $2 \mathrm{~g}$ sample was dried and weighed (accuracy of $0.0001 \mathrm{~g}$ ) in weighing bottles. Then it was dried at the temperature of $105^{\circ} \mathrm{C}$ in a drying oven to constant weight and the moisture estimation was calculated [15]. Ash content values were measured according to the handbook [16], and a $3 \mathrm{~g}$ sample was taken for determination. Crude fat was evaluated via the Soxhlet method. Diethyl ether was used for fat extraction from samples and distillation was repeated until the diethyl ether became colorless in the extraction chamber [17]. The Bertrand's method was carried out to determine reducing sugar in the sample [18]. 
The crude protein concentration was evaluated by the Kjeldahl nitrogen determination. In this method, sulfuric acid $\left(\mathrm{H}_{2} \mathrm{SO}_{4}\right)$ and chloric acid $\left(\mathrm{HClO}_{4}\right)$ were used in digestion, and this process was performed at a temperature of $400^{\circ} \mathrm{C}$. Then the prepared samples were distilled with $\mathrm{NaOH}$ and $\mathrm{H}_{2} \mathrm{SO}_{4}$ was in the receiving flask [19]. All the experiments were based on the weight analysis and repeated three times and the standard deviation was calculated with the MS Excel program.

\section{Results and discussion}

\section{Biochemical composition}

Biochemical composition of soybean varieties grown on the experimental field were shown in Figure 1. Total moisture of dried beans was between 6.39-7.33\%, ash content was 5.07-5.89\%, reducing sugar content was between 0.7 and $1.24 \%$, protein content was $26.3-31.5 \%$, crude fat content was 17.7$20.3 \%$. Little differences existed in the ash concentration in soybean grains, and the ash concentrations were similar to soybean seeds from Brazil, China, and the USA. The total moisture of
The calory of $100 \mathrm{~g}$ raw soybean seeds was calculated by summarizing the multiplied measure of contents of protein, crude fat, and total carbohydrate by their calory meaning.

Mineral content in ash of soybean was investigated with use of the ICP-OES (Inductively coupled plasma - optical emission spectrometry) technique in KHANLAB LLC. Macroelements such as $\mathrm{Ca}, \mathrm{Mg}$, $\mathrm{K}, \mathrm{P}$, and also 22 types of microelements in soybean sorts were calculated.

these seeds was comparable to soybean seeds from China and the USA, but not the seeds from Brazil, which was $13.02 \%$ [20].

The Severnaya-4 soybean seeds contained the highest amount of protein, $31.5 \%$, whereas the OAC vision variety contained the lowest amount of protein, $26.3 \%$. The Sibiryachka seeds had a higher concentration of crude fat, $20.3 \%$, and reducing sugar, $1.24 \%$. By calculation, the OAC vision and Nei dou-4 seeds had a higher amount of total carbohydrate.

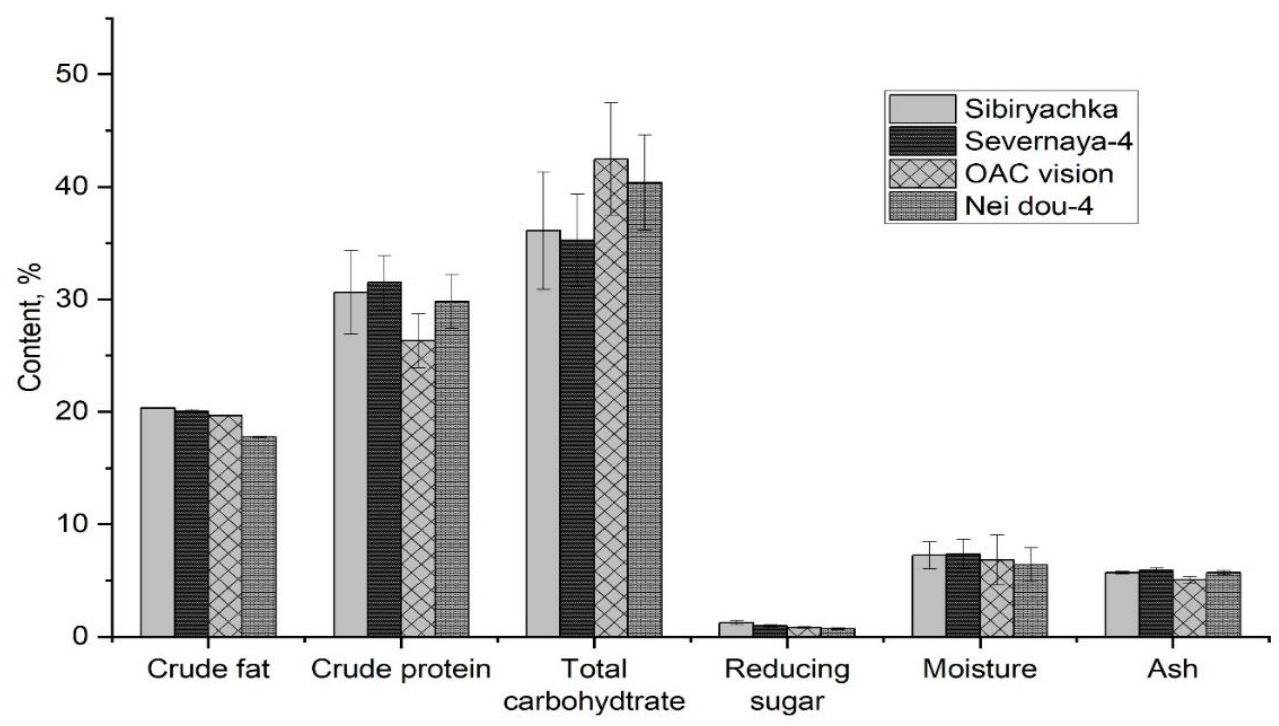

Figure 1. The results of biochemical evaluation of soybean sorts

In Figure 1, the crude fat concentration and reducing sugar concentration were positively correlated, and this relation was also observed in 60 lines of soybean seeds [21]. Our soybean cultivar seeds had a higher concentration of reducing sugar than the results of Sharma and Kaur et al., which was $0.21-0.33 \%$ [22]. Sugars in soybean seeds affect the quality, digestibility, and nutritional values of soy food products. The main sugars present in soybean seeds include glucose, fructose, sucrose, raffinose, and stachyose. Of them, glucose, fructose, and sucrose contribute to the sweet taste and are ready-to-digest. On the other hand, raffinose and stachyose are indigestible and cause undesirable flatulence and diarrhea [23]. Protein and fat content in soybean seeds are the two main characteristics of the nutrient quality of soybean seeds. And OAC vision, Sibiryachka, and Severnaya-4 seeds's fat and protein content was similar to the same varieties certified by the Ministry of Food, Agriculture and Light Industry 
in Mongolia [8, 9]. We compared our results to outcomes of other experiment, which was shown in Table 2. Seeds of the same varieties that were grown in Orkhon sum, the same experimental field of our seeds, in 2012-2014 contained a higher amount of crude fat and protein than our soybean seeds. And among soybean grains cultivated in 2012-2014 in Orkhon sum, the Nei dou -4 cultivar had the highest amount of fat and protein, $27.5 \%$ and $35.6 \%$ respectively [7]. However, in our case the Nei dou4 cultivar did not have the highest concentration of crude fat and protein.

Table 2

Comparison of fat concentration of soybean varieties

\begin{tabular}{|c|c|c|c|c|c|c|c|c|}
\hline \multirow[b]{2}{*}{ Cultivation place and year } & \multicolumn{4}{|c|}{ Fat content of Soybean varieties, $\%$} & \multicolumn{4}{|c|}{ Protein content of Soybean varieties, $\%$} \\
\hline & Sibiryachka & Severnaya-4 & OAC vision & Nei dou - 4 & Sibiryachka & $\begin{array}{c}\text { Severnaya } \\
-4\end{array}$ & $\begin{array}{l}\mathrm{OAC} \\
\text { vision }\end{array}$ & $\begin{array}{c}\text { Nei dou - } \\
4\end{array}$ \\
\hline $\begin{array}{l}\text { Orkhon sum, Darkhan Uul } \\
\text { province, 2016* }\end{array}$ & $20.35 \pm 0.02$ & $20.04 \pm 0.14$ & $19.34 \pm 0.05$ & $17.75 \pm 0.06$ & 30.6 & $31.5 \pm 2.4$ & $26.3 \pm 2.4$ & $29.8 \pm 2.4$ \\
\hline $\begin{array}{l}\text { Orkhon sum, Darkhan Uul } \\
\text { province, 2012-2014 [7] }\end{array}$ & 27.1 & 27.1 & 27.2 & 27.5 & 32.4 & 31.5 & 27.4 & 35.6 \\
\hline $\begin{array}{l}\text { Bornuur sum, Tuv } \\
\text { province, } 2012 \text { [24] }\end{array}$ & - & - & 13.52 & 14.63 & - & - & 34.31 & 41.34 \\
\hline $\begin{array}{l}\text { Kherlen river, Dornod } \\
\text { province, } 2012 \text { [24] }\end{array}$ & - & - & 21.41 & 14.74 & - & - & 28.92 & 35.25 \\
\hline Other references & $19.4-23.6^{\mathrm{ab}}$ & - & $20.6^{c}$ & - & $32.6-33.8^{\mathrm{ab}}$ & - & $42.2^{\mathrm{c}}$ & - \\
\hline
\end{tabular}

*soybeans studied in this research were cultivated in this area

${ }^{\mathrm{ab}}$ The number is taken from the website of the Russian Semennay liga's Sibiryachka variety [25], and Galeev and Vyshegurov et al.'s results [26].

${ }^{\mathrm{b}}$ The number is taken from the cultivar description [27].

In our experiment, diethyl ether was used for crude fat determination. However, there was no information on the organic solvent utilized in the Soxhlet method for soybean grains cultivated in 2012-2014 in Orkhon sum's experiment. Crude fat content of Sibiryachka seeds used in our experiment was similar to the number taken from the website of the Russian Semennay Liga's Sibiryachka variety [25] and Galeev and Vyshegurov et al.'s results [26], and the OAC vision seeds' crude fat content was similar to the cultivar description by Voldeng et al. [27]. The fat content of soybean varies between $17.2 \%$ and $18,7 \%$ among soybeans harvested from 18 areas of Brazil, China, and USA, depending on cultivars and environmental conditions [20]. In our experiment, four soybean cultivars had a slightly lower amount of crude fat content to than this result. Our soybean seeds had a lower protein concentration than soybean seeds from other experiments in Table 2. Only the Severnaya- 4 seeds contained the same amount of protein as the soybean seeds that were grown between 2012 and 2014 in the Orkhon sum. Soybean seeds from Brazil, China, and the USA had $41.53 \%$ of protein on average [20], which was also higher than our results. In the report and Grieshop and Fahey's experiment, the protein content was determined by the Kjeldahl method [7, 17]. But the method used for determining protein content in other experiments was not given. The reason why our soybean seeds contained less protein could be the cultivar of soybean, the growing environment, and soybean preservation conditions. The root zone temperature affected $\mathrm{N}_{2}$ fixation and nodule formation in soybean significantly [28]. Vollmann and Fritz et al. researched protein content of soybean seeds grown in Gross Enzersdorf (Lower Austria), and in this experiment, they observed that there was a positive correlation between the average air temperature during the seed-filling period and protein content in seeds. When the average air temperature was $19.5^{\circ} \mathrm{C}$, the protein content in seed was $43.37 \%$, and when the average air temperature was $15.8^{\circ} \mathrm{C}$, the protein content in seed dropped to $30.18 \%$ [29]. We did not find the exact temperature in August 2016 in Orkhon sum, where our soybeans were cultivated, but from the weather overview we found that in August 2016 the average air temperature was $15.1-20.0^{\circ} \mathrm{C}$ in most areas of Mongolia [30]. During the filling period of our soybean seeds (August) the average air temperature could have been lower, and therefore, these seeds had a lower protein concentration. The total calory of $100 \mathrm{~g}$ raw soybean seeds was calculated and it is shown below. It was noted that $100 \mathrm{~g}$ raw soybean seeds have $460 \mathrm{kcal}$ energy in Food central data [2]. Our soybean seeds had a lower amount of energy than this data. Sibiryachka and OAC vision had the highest amount of energy in $100 \mathrm{~g}$ raw seed than other two varieties. 
Table 3

Nutritional value of soybean seeds

\begin{tabular}{ccccc}
\hline Soybean variety & Sibiryachka & Severnaya-4 & OAC vision & Nei dou-4 \\
\hline Energy, kcal & $449.99 \pm 0.1$ & $447.32 \pm 0.05$ & $449.1 \pm 0.2$ & $440.39 \pm 0.15$ \\
\hline
\end{tabular}

\section{Mineral content}

The mineral content of soybean sorts was determined by KHANLAB LLC using the ICP-OES technique to evaluate the concentration of 26 types of minerals. Additionally, the Kjeldahl method was used to determine the nitrogen concentration. The $\mathrm{N}$, $\mathrm{Ca}, \mathrm{Mg}, \mathrm{K}$, and $\mathrm{P}$ content in seeds of 4 varieties were $4.21-5.04 \%, 0.14-0.22 \%, 0.16-0.20 \%, 0.44-0.73 \%$, and $0.43-0.64 \%$ respectively, and the results were shown in Table 4. Interestingly, the variety of Sibiryachka had the highest mineral content of most minerals compared to other varieties. The average amount of $\mathrm{Ca}$ and $\mathrm{Mg}$ of four soybean seeds were similar to the results of Vargas and Schuch et al. and Neto and Besen et al., but the percentage of $\mathrm{N}$ was lower and the percentage of $\mathrm{K}$ was about 2 or 3 times lower. The average amount of $\mathrm{P}$ was quite higher than the result of these two experiments $[27,28]$. A lower $\mathrm{N}$ content in soybean seeds could have resulted from a low temperature in the soil during the seed-filling period as mentioned above.

Table 4

Macroelements and microelements content of soybean varieties

\begin{tabular}{lcccccccccccccccc}
\hline Soybean & \multicolumn{4}{c}{ Macroelements, \% } \\
\cline { 2 - 7 } & $\mathrm{N}$ & $\mathrm{Ca}$ & $\mathrm{Mg}$ & $\mathrm{K}$ & $\mathrm{P}$ & $\mathrm{Ba}$ & $\mathrm{Bi}$ & $\mathrm{Sr}$ & $\mathrm{Cr}$ & $\mathrm{Cu}$ & $\mathrm{Zn}$ & $\mathrm{Li}$ & $\mathrm{Mo}$ & $\mathrm{Ni}$ & $\mathrm{Fe}$ & $\mathrm{Ti}$ \\
\hline Sibiryachka & 4.90 & 0.22 & 0.20 & 0.73 & 0.64 & 2.01 & 0.57 & 12.45 & 0.63 & 15.08 & 36.29 & 0.95 & 11.32 & 6.69 & 11.97 & 3.73 \\
Severnaya-4 & 5.04 & 0.22 & 0.20 & 0.52 & 0.61 & 2.01 & 0.57 & 11.63 & 0.60 & 12.84 & 33.17 & 0.29 & 9.72 & 7.02 & 11.40 & 2.13 \\
OAC vision & 4.21 & 0.16 & 0.16 & 0.52 & 0.52 & 1.15 & 0.64 & 8.83 & 0.32 & 13.04 & 28.67 & 0.27 & 19.05 & 2.77 & 9.63 & 1.68 \\
Nei dou-4 & 4.77 & 0.14 & 0.16 & 0.44 & 0.43 & 1.37 & 0.57 & 7.23 & 0.57 & 8.77 & 26.33 & 0.47 & 3.88 & 3.86 & 9.12 & 1.95 \\
\hline
\end{tabular}

In soybean seeds of four varieties contents of some elements were higher than other microelements, and these elements were $\mathrm{Sr}, \mathrm{Cu}, \mathrm{Zn}, \mathrm{Mo}, \mathrm{Ni}, \mathrm{Fe}$, and $\mathrm{Ti}$. Unfortunately, in the data we received, contents of $\mathrm{Be}, \mathrm{Cd}, \mathrm{Ga}, \mathrm{La}, \mathrm{Pb}, \mathrm{Sb}, \mathrm{Se}, \mathrm{Co}, \mathrm{Zr}, \mathrm{V}$, and $\mathrm{Y}$ in ash were similar to all varieties. The content of these elements could have been undetectable because of the small amount of ash we had sent to the company. Therefore, we eliminated these results.

\section{Conclusion}

In this work, we had determined the nutritional value and chemical composition of four soybean varieties. Among them, the Severnaya-4 and Sibiryachka varieties had the highest concentration of protein, crude fat and reduced sugar. Generally, the fat concentration of four varieties was similar to results of other experiments. However, the lower concentration of protein of these four soybean varieties was probably due to the lower environmental temperature during the seed-filling
Concentrations of $\mathrm{Cu}, \mathrm{Fe}$, and $\mathrm{Zn}$ in soybean seeds were evaluated by Vargas and Schuch et al. and Neto and Besen et al. [27, 28]. The soybean grains of four varieties had lower concentrations of $\mathrm{Cu}$ and $\mathrm{Fe}$, especially the concentration of Fe was about 9 to 6 times lower in our soybean seeds. The concentration of $\mathrm{Zn}$ was similar to Vargas and Schuch et al. work [31].

period. With regard to the minerals' contents, the Severnaya-4 and Sibiryachka soybean seeds had the highest amount.

Sibiryachka and OAC vision had the highest amount of energy in $100 \mathrm{~g}$ raw seed than other two varieties. As a result, the Severnaya-4 and Sibiryachka soybean seeds could be better sources for protein, fat and mineral than the Nei dou-4 and OAC vision varieties. 


\section{References}

1. Messina M. (2016) Soy and Health Update: Evaluation of the Clinical and Epidemiologic Literature. Nutrients. 8(12), 854. doi:10.3390/nu8120754.

2. USDA. (2018) Food Composition Databases Show Foods - Soybeans, Mature Seeds, Raw. National Nutrient Database for Standard Reference Legacy Release. https://ndb.nal.usda.gov/.

3. Gorissen S.H.M. and Witard O.C. (2018) Characterising the Muscle Anabolic Potential of Dairy, Meat and Plant-Based Protein Sources in Older Adults. Proceedings of the Nutrition Society. $20-31$. doi:10.1017/S002966511700194X.

4. Singh G. and Shivakumar B.G. (2010) The Role of Soybean in Agriculture. In: Singh, G. (ed.). The Soybean: Botany, Production and Uses. CABI. 24-47. doi:10.1079/9781845936440.0024.

5. Salvagiotti F., Cassman K.G., Specht J.E., Walters D.T., Weiss A. and Dobermann A. (2008) Nitrogen Uptake, Fixation and Response to Fertilizer N in Soybeans: A Review. F. Crop. Res. 108(1), 1-13. doi:10.1016/j.fcr.2008.03.001.

6. Tuul D. and Bayarsaikhan B. (2011) Application of the $15 \mathrm{~N}$ Isotope Technique in Soil and Plant Studies. Mong. J. Agric. Sci. 690-94.

7. (2015) Report on the Study of Soybean Varieties in the Central Crop Region, the Time of Sowing and the Effect of Seed Norms. Darkhan-Uul province.

8. Ministry of Food A. and L.I. in M. (2017) List of Varieties Discussed and Approved at the Meeting of the State Variety Testing Council on December 26, 2017. https://mofa.gov.mn/.

9. Dorligsuren A. The Role and Importance of Legumes in Improving Soil Fertility. www.dmknl.de.

10. Ministry of Food A. and L.I. in M. (2014) List of Varieties Discussed and Approved at the Meeting of the State Variety Testing Council on December 17, 2014. https://mofa.gov.mn/.

11. Carroll K.K. (1991) Review of Clinical Studies on Cholesterol-Lowering Response to Soy Protein. J. Am. Diet. Assoc. 91(7), 820-827. https://pubmed.ncbi.nlm.nih.gov/2071797/.

12. Steele M.G. (1992) Effect on Serum Cholesterol Levels of Substituting Milk with a Soya Beverage. Aust. J. Nutr. Diet. 49(1), 2428. https://agris.fao.org/agris-
search/search.do?recordID=US201301753873.

13. Lovati M.R., Manzoni C., Gianazza E. and Sirtori C.R. (1998) Soybean Protein Products as Regulators of Liver Low-Density Lipoprotein Receptors. I. Identification of Active $\beta$ Conglycinin Subunits. J. Agric. Food Chem. 46(7), 2474-2480. doi:10.1021/jf980099h.

14. Jooyandeh H. (2011) Soy Products as Healthy and Functional Foods. Middle-East J. Sci. Res. 7(1), 71-80. https://kingsvegetarianfood.ca/wpcontent/uploads/2017/02/SoyProductsasHealth yandFunctionalProducts.pdf.

15. Isaac A. (1990) Plants. In: Helrich, K. (ed.). Official Methods of Analysis of the AOAC. 15th ed. Association of official analytical chemists, Arlington, VA. 40-68.

16. Dagvatseren B., Narantsetseg G., Khishigjargal L., Zina S., Oyun Z. and Batchimeg O. (2005) Handbook of Proper Use of Herbal Medicines. Admon, Ulaanbaatar. 37-39.

17. Soxhlet F. v. (1879) Die Gewichtsanalytische Bestimmung Des Milchfettes. Dingler's $\begin{array}{lll}\text { Polytech. } & J & \text { 232461-465. }\end{array}$ http://dingler.culture.huberlin.de/article/pj232/ar232136.

18. Tsevegsuren N. and Purev D. (2001) Bioorganic Chemical Practicum. Tsevegsuren, N. (ed.). 1st ed. Urlakh erdem, Ulaanbaatar.

19. Kjeldahl J. (1883) Neue Methode Zur Bestimmung Des Stickstoffs in Organischen Körpern" (New Method for the Determination of Nitrogen in Organic Substances). Zeitschrift für Anal. Chemie. 22(1), 366-383. https://doi.org/10.1007/BF01338151.

20. Grieshop C.M. and Fahey G.C. (2001) Comparison of Quality Characteristics of Soybeans from Brazil, China, and the United States. J. Agric. Food Chem. 49(5), 2669-2673. doi:10.1021/jf0014009.

21. Hymowitz T., Collins F.I., Panczner J. and Walker W.M. (1972) Relationship Between the Content of Oil, Protein, and Sugar in Soybean Seed 1. Agron. J. 64(5), 613-616. doi:10.2134/agronj1972.000219620064000500 19x.

22. Sharma S., Kaur M., Goyal R. and Gill B.S. (2014) Physical Characteristics and Nutritional Composition of Some New Soybean (Glycine Max (L.) Merrill) Genotypes. J. Food Sci. Technol. 51(3), 551-557. doi:10.1007/s13197011-0517-7.

23. Hou A., Chen P., Shi A., Zhang B. and Wang Y.-J. (2008) Sugar Variation in Soybean Seed 
Assessed with a Rapid Extraction and Quantification Method. Ortiz, R. (ed.). Int. J. Agron. Hindawi Publishing Corporation. 2009484571. doi:10.1155/2009/484571.

24. Tsogtsaran B., Choijamts A. and Odgerel B. (2013) The Result of Soybean Varieties' Selection. Mong. J. Agric. Sci. 10(1), 106-109. https://doi.org/10.5564/mjas.v10i1.305.

25. Soy Variety

Siberiyachka. https://semliga72.ru.

26. Galeev R.R., Vyshegurov S.K., Samarin I.S., Demshina V.S. and Gumel M.A. (2018) Yield Capacity and Grain Quality of Soybeans Depending on Agrotechnical Cultivation Methods. J. Pharm. Sci. Res. 10(7), 1668-1671.

27. Voldeng H.D., Cober E.R. and Guillemette R.J.D. (2003) Kamichis Soybean. Can. J. Plant Sci. 83(1), 105-106. doi:10.4141/P02-070.

28. Zhang F., Lynch D.H. and Smith D.L. (1995) Impact of Low Root Temperatures in Soybean [Glycine Max. (L.) Merr.] on Nodulation and Nitrogen Fixation. Environ. Exp. Bot. 35(3), 279-285. doi:10.1016/0098-8472(95)00017-7.

29. Vollmann J., Fritz C.N., Wagentristl H. and Ruckenbauer P. (2000) Environmental and
Genetic Variation of Soybean Seed Protein Content under Central European Growing Conditions. J. Sci. Food Agric. 80(9), 13001306. doi:10.1002/10970010(200007)80:9<1300::AIDJSFA640>3.0.CO;2-I.

30. (2017) Weather Overview in Agricultural Area in $2016.2 \mathrm{http} / /$ tsagagaar.gov.mn/observation/agricultural/.

31. Vargas R.L. de, Schuch L.O.B., Barros W.S., Rigo G.A., Szareski V.J., Carvalho I.R., Pimentel J.R., Troyjack C., Jaques L.B.A., Souza V.Q. de, Rosa T.C. da, Aumonde T.Z. and Pedó T. (2018) Macronutrients and Micronutrients Variability in Soybean Seeds. $J$. Agric. Sci. 10(4), 209-222. doi:10.5539/jas.v10n4p209.

32. Neto M.E., Besen M.R., Coneglian C.F., Minato E.A., Lima R.S., Inoue T.T. and Batista M.A. (2018) Macro and Micronutrient Contents in Grain and Soybean Yield [Glycine Max (L). Merr.] after Foliar Application of Elemental Sulfur. Rev. Ciências Agrárias. 41(4), 71-80. doi:10.19084/RCA17268. 